\title{
Effect of Lateral Cyclic Loading on Drilled Shaft within an MSE Wall
}

\author{
Jie Huang ${ }^{1, *}$, Saidur Rahman ${ }^{2}$, Sazzad Bin-Shafique ${ }^{1}$, Chao Zheng ${ }^{1}$, and Sandeep Malla ${ }^{1}$ \\ ${ }^{1}$ Department of Civil and Environmental Engineering, University of Texas at San Antonio, One UTSA Circle, San Antonio, TX 78249 \\ ${ }^{2}$ KMA Consulting Engineers, Inc., 1010 Berlin Road, Cherry Hill, NJ 08034
}

\begin{abstract}
Drilled shafts are often subjected to various lateral loads due to earth pressure, wind loads and/or impact loads. Many studies have investigated the behavior of drilled shafts under lateral loads. However, there is limited study on the effect of cyclic loading on drilled shafts, which is of great importance during a hurricane strike. This paper encompasses a numerical study using three-dimensional (3D) finite difference software, FLAC3D, which investigated interaction between a drilled shaft and an MSE wall under cyclic loading event. The backfill material was simulated by a stress-dependent model, which can account for the hardening due to confining stresses. The interactions between dissimilar materials were represented by frictional interface at the contacts. The numerical simulation scrutinized the effects of soil friction angle and the loading cycles on the performance of the drilled shaft and MSE wall under both loading and unloading conditions. The result indicates that the cyclic loading leads to gradual accumulation of the displacement, which cannot be effectively considered in current design method.
\end{abstract}

\section{Introduction}

Acting as foundations of bridges, highway interchanges, and retaining structures, drilled shafts need to provide substantial resistance to significant lateral loads induced by wind pressure, water flow, earth pressure, ground excitation etc. [1, 2]. Originated from the theory of Beam on Elastic Foundation (BEF), the method to evaluate the response of a laterally loaded drilled shaft in soil/rock has been well established [3,4], which is often called the p-y curve method in practice. Many researchers proposed different $\mathrm{p}$-y curves (i.e., $\mathrm{p}(\mathrm{x})$ ) for different type of soil, which are primarily based on lateral loading tests of piles/shafts as listed in Table 1.

Table 1. p-y curves for different soils.

\begin{tabular}{|c|c|c|c|}
\hline $\begin{array}{c}\text { Type of p-y } \\
\text { curve }\end{array}$ & $\begin{array}{c}\text { Test pile } \\
\text { diameter } \\
\text { (inches) }\end{array}$ & $\begin{array}{c}\text { Type of } \\
\text { piles }\end{array}$ & Reference \\
\hline Soft clay criteria & 12.75 & Steel pile & {$[3]$} \\
\hline $\begin{array}{c}\text { Stiff Clay Criteria } \\
\text { (above water } \\
\text { table) }\end{array}$ & 30 & $\begin{array}{c}\text { Steel pipe } \\
\text { pile }\end{array}$ & {$[4]$} \\
\hline $\begin{array}{c}\text { Stiff Clay Criteria } \\
\text { (below water } \\
\text { table) }\end{array}$ & 24 & Drilled shaft & {$[4]$} \\
\hline Sand criteria & 24 & Drilled shaft & {$[5]$} \\
\hline Weak rock & 48 & Drilled shaft & {$[6]$} \\
\hline
\end{tabular}

Although there were disputes to simplify the soil/rock response with non-linear springs, numerous field tests have verified the applicability of p-y curves methods for both piles and drilled shafts for many applications [for example, 7-10]. Nowadays, the commonly used p-y curves have been incorporated into numerical software packages, such as COM624, LPILE, and FB-Pier, to facilitate the daily design practice of laterally loaded piles/drilled shafts.

In recent years, drilled shafts sometimes have to be built in an MSE wall to support lateral loads, primarily from wind and/or seismic loads. Under this circumstance, the existing p-y curves are not applicable. Due to lack of information, Pierson et al. [11] performed a study to assess the behavior of drilled shafts in an MSE wall and provided a threshold lateral deflection of the drilled shaft that a MSE wall can tolerate. Rollins et al. [12] then studied driven pile in an MSE wall and suggested additional load to be considered in the drilled shaft and MSE wall design during a seismic event. No study has been completed to assess the effect of a cyclic loading on drilled shaft if built in an MSE wall.

\section{Numerical simulation}

This study, based on numerical simulation, focuses on investigating the behavior of drilled shafts under cyclic lateral loading if built in an MSE wall. The prototype drilled shaft is presented in Figure 1, which was built within a $6 \mathrm{~m}$ MSE wall. The drilled shaft was $0.9 \mathrm{~m} \mathrm{(3}$ $\mathrm{ft}$ ) in diameter and had a total embedded length of $6 \mathrm{~m}$ in the MSE wall. The neighboring drilled shafts were spaced at $9 \mathrm{~m}$ to minimize the interaction.

\footnotetext{
* Corresponding author: jie.huang@utsa.edu
} 


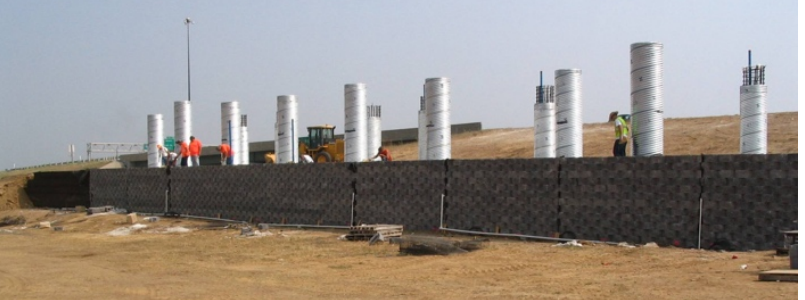

Fig. 1. Drilled shafts in MSE wall to support lateral loads (Courtesy of Jie Han).

\subsection{Constitutive models}

Five different constitutive models are used for the backfill material, grade soil, retained soil, foundation soil, drilled shaft, and geogrid materials, which are shown in Table 2. The modulus of elasticity and Poisson's ratio of the MSE wall facing blocks are considered as $2 \mathrm{GPa}$ and 0.25 , respectively. The MohrCoulomb failure criteria have been considered for foundation soil, grade soil, and retained soil. The elastic modulus, cohesion, and friction angle were used as 9 $\mathrm{GPa}, 25 \mathrm{MPa}$, and $40^{\circ}$, respectively for the foundation rock [11]. The friction angle and cohesion of sandy clay retained soil was used $30^{\circ}$ and $1 \mathrm{kPa}$, respectively. Table 2 summarizes the constitutive models that were used for the numerical model of the MSE structure systems. In addition, the geogerid used in the study was assumed linear elastic materials. Bottom four layers were UX1500 and top six layers were UX1400, which were spaced at $0.6 \mathrm{~m}$ vertically.

Table 2. Constitutive model and material properties (Modified after [13]).

\begin{tabular}{|c|c|c|}
\hline $\begin{array}{c}\text { MSE } \\
\text { structure } \\
\text { elements } \\
\end{array}$ & $\begin{array}{c}\text { Constitutive } \\
\text { model of } \\
\text { element } \\
\end{array}$ & Material properties \\
\hline Drilled shaft & Elastic & $\begin{array}{c}\mathrm{E}=30 \mathrm{GPa}, v=0.3, \gamma=25 \\
\mathrm{kN} / \mathrm{m}^{3}\end{array}$ \\
\hline $\begin{array}{l}\text { Facing } \\
\text { blocks }\end{array}$ & Elastic & $\begin{array}{c}\mathrm{E}=2 \mathrm{GPa}, \mathrm{v}=0.25, \gamma=15 \\
\mathrm{kN} / \mathrm{m}^{3}\end{array}$ \\
\hline \multirow{4}{*}{ Backfill soil } & $\begin{array}{c}\text { Linearly-elastic } \\
\text { perfectly-plastic } \\
(5.4-6 \mathrm{~m}) \\
\end{array}$ & $\begin{array}{c}\mathrm{E}=30 \mathrm{GPa}, v=0.3, \gamma=18 \\
\mathrm{kN} / \mathrm{m}^{3}, \phi=30^{\circ} \mathrm{c}=800 \mathrm{~Pa}\end{array}$ \\
\hline & Cysoil (4-5.4 m) & $\begin{array}{c}\alpha=1, \mathrm{v}=0.2, \gamma=18 \mathrm{kN} / \mathrm{m}^{3}, \\
\phi_{f}=48^{\circ}, R_{f}=0.9, K_{r e f}=12.2 \\
\mathrm{Mpa}, G_{r e f}=9.17 \mathrm{Mpa}\end{array}$ \\
\hline & Cysoil (2-4 m) & $\begin{array}{c}\alpha=1, v=0.2, \gamma=18 \mathrm{kN} / \mathrm{m}^{3}, \\
\phi_{f}=48^{\circ}, R_{f}=0.9, K_{r e f}=16.6 \\
\mathrm{Mpa}, G_{r e f}=12.5 \mathrm{Mpa}\end{array}$ \\
\hline & Cysoil (0-2 m) & $\begin{array}{c}\alpha=1, v=0.2, \gamma=18 \mathrm{kN} / \mathrm{m}^{3}, \\
\phi_{f}=48^{\circ}, R_{f}=0.9, K_{r e f}=27.7 \\
\mathrm{Mpa}, G_{r e f}=20.83 \mathrm{Mpa}\end{array}$ \\
\hline $\begin{array}{l}\text { Retained } \\
\text { soil }\end{array}$ & $\begin{array}{l}\text { Linearly-elastic } \\
\text { perfectly-plastic }\end{array}$ & $\begin{array}{c}\mathrm{E}=30 \mathrm{GPa}, v=0.3, \gamma=17.5 \\
\mathrm{kN} / m^{3}, \phi=35^{\circ}, \mathrm{c}=0 \mathrm{kPa}\end{array}$ \\
\hline Grade soil & $\begin{array}{l}\text { Linearly-elastic } \\
\text { perfectly-plastic }\end{array}$ & $\begin{array}{c}\mathrm{E}=30 \mathrm{GPa}, v=0.3, \gamma=17.5 \\
\mathrm{kN} / \mathrm{m}^{3}, \phi=40^{\circ}, \mathrm{c}=0 \mathrm{kPa}\end{array}$ \\
\hline $\begin{array}{c}\text { Foundation } \\
\text { soil }\end{array}$ & Elastic & $\begin{array}{c}\mathrm{E}=30 \mathrm{GPa}, v=0.3, \gamma=17 \\
\mathrm{kN} / \mathrm{m}^{3}\end{array}$ \\
\hline
\end{tabular}

The backfill soil was modeled using two different constitutive models. Mohr-Coulomb constitutive model was used at the top $0.6 \mathrm{~m}$ of the low permeability soil. The remaining $5.4 \mathrm{~m}$ of backfill soil was simulated by Cap-Yield soil in FLAC3D [14]. Cap-Yield can consider the stress-dependent behavior of granular materials, so it was selected for this study. More discussion about using Cap-Yield model for an MSE wall simulation can be found in Huang et al. [12]. For a Cap-Yield model, the shear and compression yielding are governed by the criteria in Eqs. 1 and 2, respectively.

$$
\begin{aligned}
& f^{s h}=\mathrm{M} p^{\prime}-\mathrm{q} \\
& f^{c p}=\frac{q^{2}}{\alpha^{2}}+p^{2}-p_{c}^{2}
\end{aligned}
$$

where $\mathrm{f}^{\mathrm{sh}}$ is shear yielding function; $\mathrm{f}^{\mathrm{fp}}$ is compression yielding function $\delta=\left(3+\sin \phi_{m}\right) /\left(3-\sin \phi_{m}\right) ; \mathrm{M}=6 \sin \phi_{m}$ $/\left(3-\sin \phi_{m}\right) ; \mathrm{p}^{\prime}=\left(\sigma_{1}{ }^{\prime}+\sigma_{2}{ }^{\prime}+\sigma_{3}{ }^{\prime}\right) / 3 ; \mathrm{q}=\left(\sigma_{1}{ }^{\prime}+(\delta-1) \sigma_{2}{ }^{\prime}-\delta \sigma_{3}{ }^{\prime}\right)$, $\phi_{m}$ is mobilized friction angle.

The equation of the plastic shear modulus $\left(G^{p}\right)$ and tangent shear modulus $\left(G^{e}\right)$ are given in Eqs. 3 and 4.

$$
\begin{aligned}
G^{p} & =\beta G^{e}\left(1-\frac{\sin \phi_{m}}{\sin \phi_{f}} R_{f}\right)^{2} \\
G^{e} & =G_{r e f}^{e}\left(\frac{p^{\prime}}{p_{r e f}}\right)^{m}
\end{aligned}
$$

where $p_{\text {ref }}$ is the reference mean stress; $\mathrm{G}^{\mathrm{e}}$ ref is the stress modulus at the reference pressure, $p_{\text {ref }} ; \phi_{\mathrm{f}}$ is the ultimate friction angle; and $\mathrm{R}_{\mathrm{f}}$ is a constant which is less than 1 .

Plastic shear strain, $\gamma^{p}$, can be formulated in Eq. 5.

$$
\gamma^{p}=\frac{p_{r e f}}{G_{r e f}^{e}}\left(\frac{p^{\prime}}{p_{r e f}}\right)^{1-m} \frac{\sin \phi_{f}}{R_{f}}\left[\frac{1}{1-\frac{\sin \phi_{m}}{\sin \phi_{f}} R}-1\right]
$$

The shear yielding follows the associated flow rule whereas compression yielding follows a non-associated flow rule. The non-associated flow rule is formulated in Eq. 6. The isotropic compression hardening has not been considered for the laterally loaded drilled shaft because volumetric strain is not the focus in this study.

$$
\mathrm{g}=\sigma_{1}^{\prime}-\sigma_{3^{\prime}}
$$

where $\sigma_{1}$ and $\sigma_{3}$ are major and minor principle stresses, respectively.

The interface between MSE wall facing blocks was mimicked by a linearly elastic perfectly plastic MohrCoulomb sliding behavior. The interface friction angle and cohesion has been used to be $57^{\circ}$ and $46 \mathrm{kPa}$, respectively [15]. The side interface friction angle and cohesion of the block has been used $19.5^{\circ}$ and cohesion of $0.5 \mathrm{kPa}$, which were taken based on Ling et al. [16] and Liu and won [17]. The direct shear test data has been used to calculate interface shear and normal stiffness [15]. The slip joints were considered as smooth surface between each section. The geometry of MSE wall facing blocks is shown in Figure 2. In addition, the same interface model was used at the contacts between all 
dissimilar materials. The properties of these interfaces are listed in Table 3. (a)

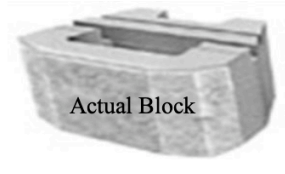

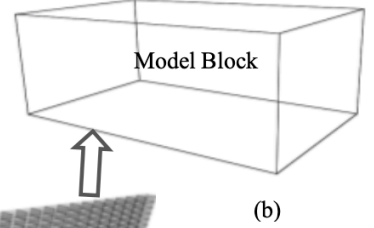

(b)

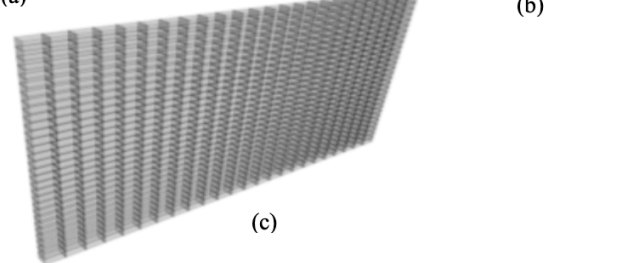

Fig. 2. Geometry of one MSE wall facing block: (a) one MSE block; (b) One model block in model (not in scale); and (c) simulated MSE facing blocks.

Table 3. Different interface properties.

\begin{tabular}{|c|c|c|}
\hline Interface type & & Interface properties \\
\hline \multirow{2}{*}{$\begin{array}{l}\text { MSE wall facing } \\
\text { blocks }\end{array}$} & Horizontal & $\begin{array}{c}\phi_{i}=57^{\circ}, c_{i}=46 \mathrm{kPa}, k_{s}= \\
40 \mathrm{MN} / \mathrm{m} / \mathrm{m}, k_{n}=40 \\
\mathrm{MN} / \mathrm{m} / \mathrm{m}\end{array}$ \\
\hline & Vertical & $\begin{array}{c}\phi_{i}=19.5^{\circ}, c_{i}=0.5 \mathrm{kPa} \\
k_{s}=40 \mathrm{MN} / \mathrm{m} / \mathrm{m}, k_{n}=40 \\
\mathrm{MN} / \mathrm{m} / \mathrm{m}\end{array}$ \\
\hline \multicolumn{2}{|c|}{$\begin{array}{l}\text { MSE wall facing blocks and } \\
\text { backfill soil }\end{array}$} & $\begin{array}{c}\phi_{i}=44^{\circ}, c_{i}=0 \mathrm{MPa}, k_{s} \\
=40 \mathrm{MN} / \mathrm{m} / \mathrm{m}, k_{n}=40 \\
\mathrm{MN} / \mathrm{m} / \mathrm{m}\end{array}$ \\
\hline \multicolumn{2}{|c|}{ Drilled shaft and backfill soil } & $\begin{array}{c}\phi_{i}=41^{\circ}, c_{i}=0.23 \mathrm{MPa}, \\
t_{i}=0.6 \mathrm{MPa}, k_{s}=15.38 \\
\mathrm{MN} / \mathrm{m} / \mathrm{m}, k_{n}=33.33 \\
\mathrm{MN} / \mathrm{m} / \mathrm{m}\end{array}$ \\
\hline
\end{tabular}

\subsection{Simulation procedure}

The study investigated the effect of cycles of loading and backfill soil friction angle. The parameters are summarized in Table 4. The lateral load was a concentrated force of $250 \mathrm{kN}$ applied at the head of the drilled shaft, which is about the load exerted by a wind of $120 \mathrm{mph}$ on a $2 \times 2 \mathrm{~m}^{2}$ area. The geometry and mesh of the numerical model are presented in Figure 3.

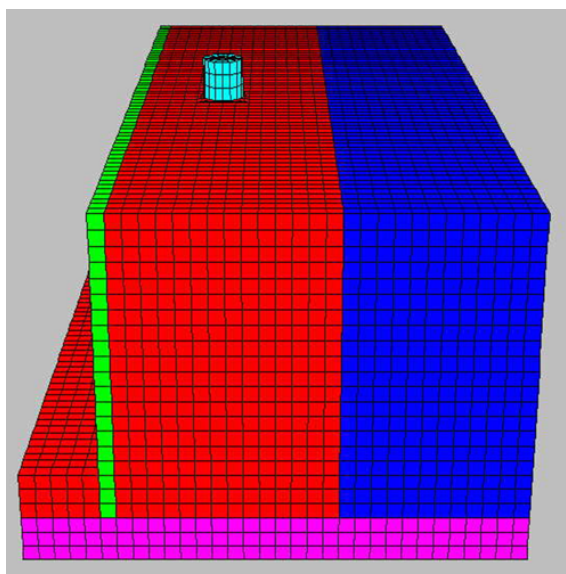

Fig. 3. Numerical model.

Table 4. Parameters and their variation for parametric study.

\begin{tabular}{|c|c|c|}
\hline Item no. & $\begin{array}{c}\text { Name of parametric } \\
\text { study items }\end{array}$ & Description of items \\
\hline 1 & Friction angle & $30^{\circ}, 35^{\circ}, 40^{\circ}$, and $48^{\circ}$ \\
\hline
\end{tabular}

\section{Results and discussions}

The results yielded from numerical simulation are presented in Figures 4 - 7, respectively. Figures 4 and 5 show the evolvement of drilled shaft displacement at the loading and unloading cycles, respectively. It is clear that with more loading cycles the displacement increases gradually. The increase is less salient after 5 loadingunloading cycles. Compared with loading cycles, the displacement increase is much more significant in unloading cycles, which may be attributed to the accumulation of residual strain. The friction angle does not show noticeable effect on reducing displacement under cyclic loading.

Figures 6 and 7 illustrate the displacement of the MSE wall under loading and unloading conditions. According to these two figures, the cyclic loading shows a more profound effect on MSE wall than on drilled shaft. The MSE wall displacement increases at least $20 \%$ after 12 loading cycles and $30 \%$ after 12 unloading cycles. All of the figures for drilled shaft and MSE wall seem to show that the increase of displacement due to cyclic loading is primarily limited in the first few cycles, which should be considered in design.

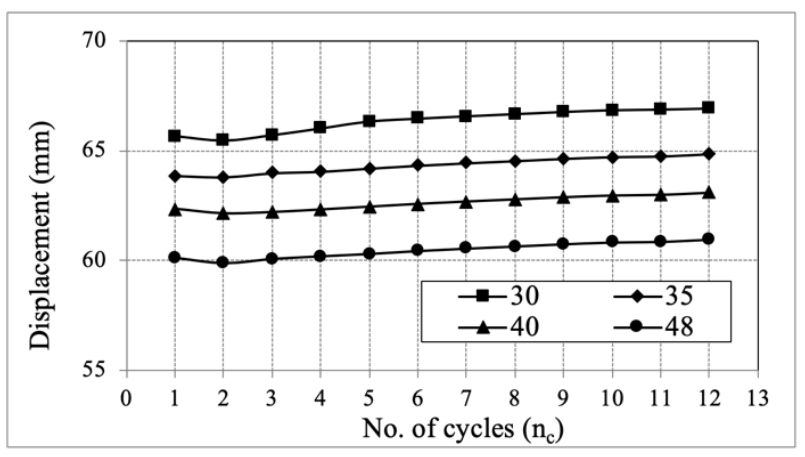

Fig. 4. Increase of top drilled shaft displacement in twelve loading cycles due to different friction angle.

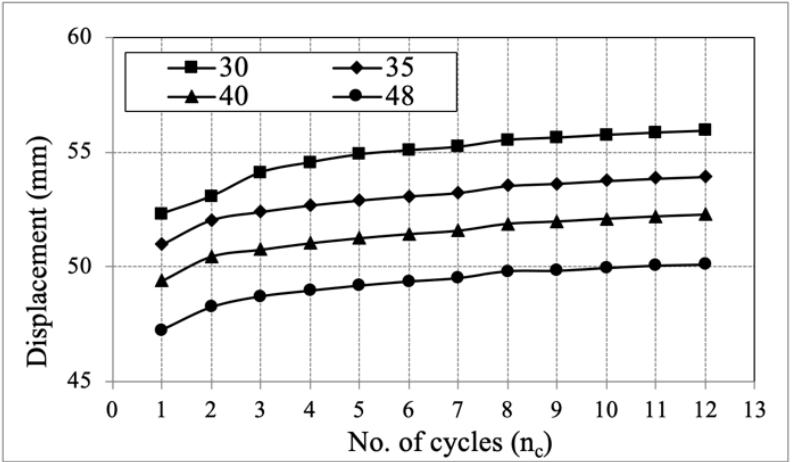

Fig. 5. Increase of top drilled shaft displacement in twelve unloading cycles due to different friction angle. 


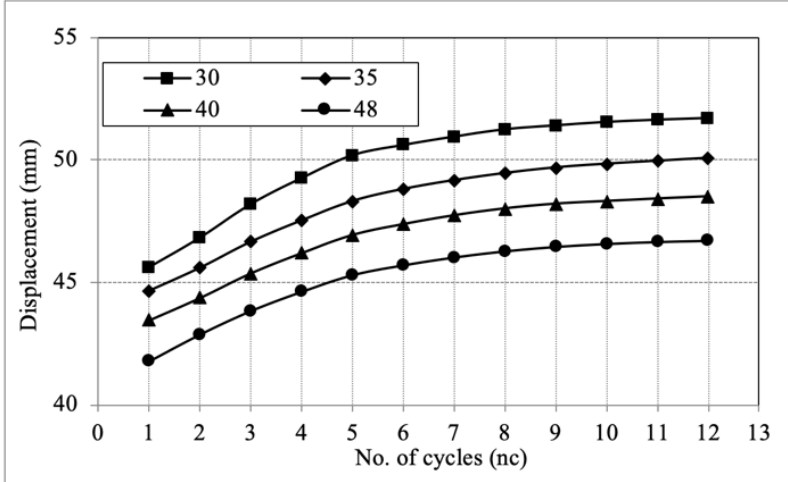

Fig. 6. Increase of MSE wall displacement in twelve loading cycles for different friction angle.

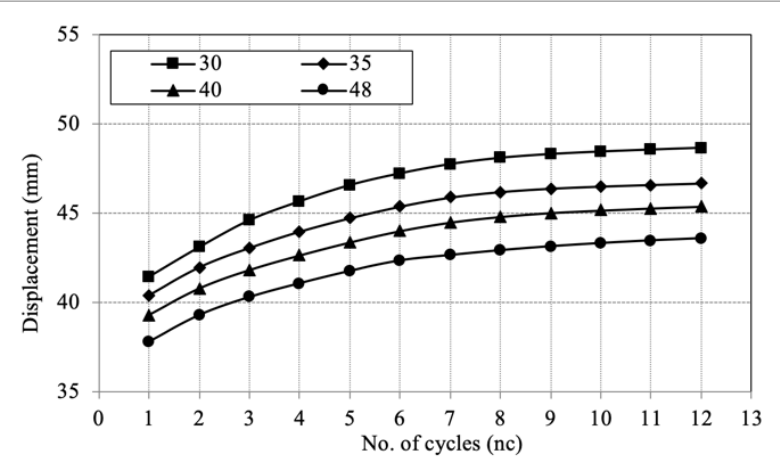

Fig. 7. Increase of MSE wall displacement in twelve unloading cycles for different friction angle.

\section{Conclusions}

Based on the completed study, the following conclusion can be drawn:

- The cycle loading has considerable effect on the displacement of drilled shaft and MSE wall. That is, the cyclic loading leads to the increase of the displacement, which could be more than $30 \%$ for 12 cycles.

- The primarily increase plausibly is attributable to the first few cycles.

- An increase of friction angle may reduce total displacement but may not lessen the effect of cyclic lateral loading.

\section{References}

1. Salgado, R. (2008). The Engineering of Foundations, McGraw Hill, 882p.

2. Brown, D.A., Turner, J.P., and Castelli, R.J. (2010). Drilled Shafts: Construction Procedure and LRFD Design methods. FHWA NHI-10-016, 970

3. Matlock, H. (1970). Correlation for Design of Laterally Loaded Piles in Soft Clays. Proceeding of the 2nd Annual OTC. Dallas, Texas.

4. Reese, L., \& Welch, R.C. (1975). Lateral loading of deep foundations in stiff clay. Proceeding, ASCE, 101(GT7), 633-649.

5. Reese, L.C., Cox, W.R., \& Koop, F.D. (1974). Analysis of laterally loaded piles in sand.
Proceeding of Fifth Annual Offshore Technical Conference, Paper No. OTC 2080. Houston Texas.

6. Reese, L.C. (1997). Analysis of laterally loaded piles in weak rock. Journal of Geotechnical and Geoenvironmental Engineering, 123(11), 10101017.

7. Bierschwale, M.W., Coyle, H.M., and Bartoskewitz R.E. (1981). Field Tests and New Design Procedure for Laterally Loaded Drilled Shafts in Clay, FHWA/TX-81/09+211-3F, 129p.

8. Gabr, M.A., Borden, R.H., Cho, K.H., Clark, R.C., and Nixon, J.B. (2002). P-y Curves for Laterally Loaded Drilled Shafts Embedded in Weathered Rock. FHWA/NC/2002-008

9. Yang, K. (2006). Analysis of Laterally Loaded Drilled Shafts in Rock, University of Akron, Ph.D. dissertation.

10. Pierson, M.C., Parsons, R.L., Han, J., and Brennan, J.J., (2011). Laterally loaded shaft group capacities and deflections behind an mse wall, Journal of Geotechnical and Geoenvironmental Engineering, 137(10), 882-889.

11. Pierson, M.C., Parsons, R.L., Han, J., Brown, D.A., and Thompson, R.W. (2008). Capacity of laterally loaded shafts constructed behind the face of a mechanically stabilized earth block wall. Final Report, Kansas Department of Transportation.

12. Rollins, K.M., Gerber, T.M., and Heiner, L. (2010). Passive force-deflection behavior for abutments with MSE confined approach fills. Utah Department of Transportation Final Report, UT-10.15.

13. Huang, J., Han, J., Parsons, R.L., and Pierson, M., Refined numerical modeling of a laterally loaded drilled shaft in an MSE wall. Geotextiles and Geomembranes, 37, 2013, 61-73.

14. Itasca Consulting Group (2009). FLAC3D Theory and Background, Itasca Consulting Group Inc., 226pp.

15. Huang, B., Bathurst, R.J., and Hatami, K. (2009). Numerical Study of Reinforced Soil Segmental Walls using Three Different Constitutive Soil Models. Journal of Geotechnical and Geoenviornmental Engineering, 135(10): 14861498.

16. Ling, H.I. and Leshchinsky, D. (2003). Finite element parametric study of the behavior of segmental block reinforced soil retaining walls. Geosynthetics International, 10(3), 77-94.

17. Liu, H.B., and Won, M., (2009). Long-term reinforcement load of geosynthetic-reinforced soil retaining walls. Journal of Geotechnical and Geoenvironmental Engineering, 135(7): 875-889. 